https://doi.org/10.52449/1857-4114.2021.37-1.08

CZU: 796.015.8:796.342

\title{
FACTORS DETERMINING THE LEVEL OF HIGH QUALIFICATION AND SPORTS ACHIEVEMENTS IN LONG-TERM TRAINING OF FEMALE TENNIS PLAYERS (DIAGNOSTIC ASPECT)
}

\author{
Mocrousov Elena ${ }^{1}$, ORCID: 0000-0002-4037-4037 \\ ${ }^{1}$ State University of Physical Education and Sport, Chisinau, Republic of Moldova
}

\begin{abstract}
Table tennis is a complex analytical sport with versatile technique, various specific solutions, which has long outgrown a period of mass enthusiasm. For athletes to achieve sports results, general physical, special and psychological training is now necessary. Modern requirements to the level of special, technical, tactical and physical training of female athletes, to the entire system of their training are extremely high. In this regard, the importance of specialized factors in the sports training of female tennis players increases significantly. In the long-term training of the highly qualified female tennis players, a number of important stages is provided for, which in their structure have specific tasks and a meaningful orientation of their implementation. The task of implementing classification standards of the competitive activity of female tennis players is a complex training process that should be carried out not only taking into account general psychological and pedagogical laws, but also specific scientifically based methods and techniques of pedagogical influence, the organization of this type of activity and an individual approach.
\end{abstract}

Keywords: table tennis, functionality, qualification and sports achievements, diagnostics, methods, intellectual properties, psychomotor capacities, female tennis players.

Actuality. The long-term and effective training process in table tennis is a complex pedagogical work that depends on many factors, including the characteristics of training, education, active training of female tennis players at all stages of their training for the competitions. So, an intense task is set to fulfill the classification standards of the competitive activity of female tennis players:

- by the end of the $1^{\text {st }}$ year of training, it is necessary to fulfill the requirements of the $2^{\text {nd }}$ junior sports category;

- by the end of the $2^{\text {nd }}$ year of training, it is necessary to fulfill the requirements of the $1^{\text {st }}$ junior sports category;

- by the end of the $3^{\text {rd }}$ year of training, it is necessary to fulfill the requirements of the $3^{\text {rd }}$ adult sports category;
- by the end of the $4^{\text {th }}$ year of training, it is necessary to fulfill the requirements of the $2^{\text {nd }}$ adult sports category;

- by the end of the $5^{\text {th }}$ year of training, it is necessary to fulfill the requirements of the $1^{\text {st }}$ adult sports category or Candidate for Master of Sport;

- by the end of the $6^{\text {th }}$ year of training, it is necessary to fulfill the sports level requirements of the Candidate for Master of Sport or Master of Sport;

- by the end of the $7^{\text {th }}$ year of training, it is necessary to fulfill the requirements of the sports level of a Master of Sport or an Master of Sport or the International Class;

- by the end of the $8^{\text {th }}$ year of training, it is necessary to fulfill the requirements of the sports level of the Master of Sport of the International Class. 
The task of fulfilling the classification standards of the competitive activity of female tennis players is a complex training process that should be carried out not only taking into account general psychological and pedagogical laws, but also specific scientifically based methods and techniques of pedagogical influence, the organization of this type of activity and an individual approach $[2,3,8]$.

In this regard, it is necessary an in-depth study the factors affecting sports result, to determine the quantitative characteristics of the long-term training process and the meaningful significance of each of them in the structure of training highly qualified female table tennis athletes. In the individual-game sports activity of female tennis players, in our opinion, the leading factor of success is technical and tactical skill, for which other significant factors of the training process work [7].

A characteristic feature of table tennis is its dynamism and complexly coordinated practice, which imposes special requirements on the speed of the reactions, concentration and distribution of attention, information processing and decision-making [3, 4]. Therefore, review, accounting and implementation of sports and developing circumstances (factors) that determine adequate technical and tactical training in table tennis will be the main sign of the effectiveness of the long-term training process. These factors include: morphological characteristics of female tennis players; the state of functionality of the systems of the body of female tennis players; intellectual properties of the personality of female tennis players; psychomotor abilities of female tennis players; development of physical qualities of female tennis players; general and specialized coordination capabilities, as the basis of the technical and tactical training of female tennis players. In the article presented for publication, we will focus on such factors as morphological signs of female tennis players, the state of functionality of the systems of the body of female tennis players and the intellectual properties of the personality of female tennis players in the process of their long-term training, to determine the level of qualification and sports achievements.

The purpose of the research is to develop and scientifically substantiate the long-term training of the highly qualified female table tennis athletes, based on the optimal selection of training influences.

The object of the research is the process of long-term training of highly qualified female table tennis athletes.

The objectives of the research:

1. Study the modern aspects of the development of table tennis, the system of the training process of highly qualified female table tennis athletes, the nature and structural forms of long-term training.

2. Scientifically substantiate the main directions of a systematic approach to the long-term training process in table tennis.

3. Study the morphological features of female tennis players, intellectual capacity, the functionality of the analyzer systems of the body of female tennis players in the mode of an active educational and training process of female tennis players in long-term sports improvement.

\section{Scientific novelty and originality of the} research:

1. A new scientific direction was developed within the framework of sports pedagogy: theoretical and methodological substantiation of training highly qualified female table tennis athletes based on the optimal selection of training influences.

2. The scientific concept of training highly qualified female table tennis athletes was developed and substantiated, which includes a system of psychological, physical and pedagogical factors, as well as a system of methodological foundations: principles, macrocycles, forms and stages of training female athletes and mechanisms of training influences. 
The theoretical significance of the research is:

1. Development of the theory of physical education and sport, through the development of conceptual and methodological foundations of training highly qualified female table tennis athletes, based on the optimal selection of training influences.

2. Development of general and methodological principles of building a system of long-term training process for training highly qualified female table tennis athletes.

3. Substantiation of the relationship of psychological, physical, pedagogical and methodological factors in determining the optimal forms and methods of training influences in the process of training highly qualified female table tennis athletes.

Ensuring the optimal functionality of the analytic systems of the body of female tennis players in the mode of an active educational and training process

It is quite natural that in order to solve such a difficult task as the long-term training of highly qualified female table tennis athletes, systemic medical control of the age-related functionality of all systems of their body, both general and specialized, is necessary. So, general control should be carried out once a training year in specialized medical institutions - sports clinics. But, unfortunately, nowadays these institutions have ceased to exist, and a medical examination is carried out in polyclinics at the place of residence of the female athletes. Additional specialized medical control is prophylactic and focuses mainly on the motor sphere of the female tennis players and the state of the functionality of the analyzer systems of their body. Among the analyzing systems, it is especially necessary to highlight the visual function of the body of female tennis players, the functional normality of which ensures their success in the intense training and game process. It is especially necessary to highlight the importance of express control of the visual function of female tennis players in the educational and training process, which reflects the degree of their motor fatigue (overwork) and which is most informatively controlled by effective tools and methods of urgent diagnostics $[13,14]$.

The method for determining human fatigue by optical methods has been known for a long time. At the same time, the original method for determining human fatigue is to measure the critical frequency of fusion of fluorescent lights, perceived alternately by his eyes.

We have designed, under the conditions of the SUPES, an electronic device for determining the motor fatigue of an athlete, which allows us to measure the frequency of fusion of fluorescent lights, perceived alternately by his eyes. This device with the abbreviated name PKUZ-1 (Figure 1) makes it possible to determine not only the degree of motor fatigue of an athlete (through CFFL the coefficient of the frequency of fluorescent lights), but also the state of his visual function, which is associated with fatigue of the visual analyzer from the intense training process of female table tennis athletes.

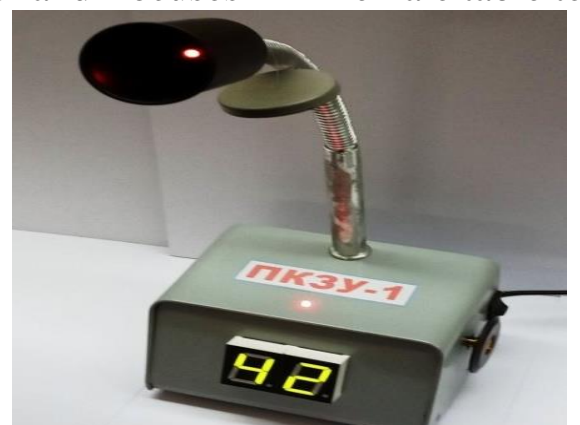

Fig. 1. The appearance of the electronic device PKZU-1, which diagnoses the functionality of the visual analyzer and motor fatigue of tennis players 
This issue is also important because the long-term sports training of female table tennis athletes provides, at the $3^{\text {rd }}$ and subsequent (up to 8 stages) annual stages, three and four training sessions per day with intensive motortechnical improvement, in which both purely motor and visual fatigue and overwork, and which, without appropriate control, entail negative functional consequences. The degree of motor fatigue of female tennis players is determined by the asymmetry of the indicators of the left and right eyes.

In so doing, their difference is calculated from the two frequency readings, and the degree of fatigue of the female athlete is determined by the obtained asymmetry. We have experimentally developed critical indicators of asymmetry to determine the qualitative level of motor fatigue of female table tennis athletes, which are presented in Table 1. As can be seen from Table 1, the initial degree of fatigue begins after 2 hours of intense training activity of a female athlete, and especially when it comes to developing the basic motor skills of female athletes: strength, speed-strength abilities, strength endurance. At the same time, the average degree of fatigue of female tennis players begins after three academic hours (within 140 minutes) of their continuous training work, which is still permissible.

Table 1. CFFL indicators for female tennis players, depending on the duration of the intensive training process

\begin{tabular}{|l|c|c|c|c|c|}
\hline \multirow{2}{*}{$\begin{array}{c}\text { Object and } \\
\text { direction of } \\
\text { measurement }\end{array}$} & \multicolumn{5}{|c|}{ CFFL and training hours } \\
\cline { 2 - 6 } & $\begin{array}{c}\text { Beginning } \\
\text { of training }\end{array}$ & $\begin{array}{c}\text { After two } \\
\text { hours }\end{array}$ & $\begin{array}{c}\text { After three } \\
\text { hours }\end{array}$ & $\begin{array}{c}\text { After four } \\
\text { hours }\end{array}$ & $\begin{array}{c}\text { After five-six } \\
\text { hours }\end{array}$ \\
\hline Left eye & 44,00 & 42,00 & 38,00 & 34,00 & 32,00 \\
\hline Right eye & 45,80 & 42,70 & 38,60 & 34,50 & 32,20 \\
\hline Asymmetry & 1,80 & 0,70 & 0,60 & 0,50 & 0,20 \\
\hline $\begin{array}{l}\text { Degree of } \\
\text { fatigue }\end{array}$ & - & Initial & Secondary & $\begin{array}{c}\text { Pre- } \\
\text { maximal }\end{array}$ & Maximal \\
\hline
\end{tabular}

Among all the systems of the body of a female table tennis athlete, it is necessary to highlight the system of analyzers, in which the visual analyzer takes the leading place for the formation of the technical perfection of the game. This analyzer, in combination with the vestibular apparatus, muscular proprioception and analytical system, provides the female athlete with a timely game reaction, the necessary movements of the player for the convenience of attack and defense, spatialdynamic orientation and stability in complex coordination movements [1].
Unfortunately, in our opinion, insufficient attention is paid to the functionality of the visual analyzer of female table tennis athletes, in view of the fact that the main playing priority of a coach and an athlete is, in most cases, the result at any "cost". And, probably, this also has its own meaning, but it seems to us that this approach is wrong, when the cause-and-effect relationships change places and contradict each other. Hence the corresponding result, which entails an agitated search for causes that were "destroyed" by the consequence and an unjustified waste of time 
on unjustified (false) technical and tactical preparatory correction of a female tennis player, which leads to a premature "breaking" of the dynamic stereotype with all the consequences $[1,11]$.

Table 2 shows the experimentally derived frequency indicators of red and green light glimpses, when they become one for the right and left eyes of a female tennis player. As can be seen from Table 2, with the red light of the LED, the flickering frequency for the normal functioning of the female tennis player's visual analyzer is $40-42$ hertz, and for green light it is slightly higher due to the peculiarities of the color perception of the eye - up to 42-45 hertz. At the same time, the lower limit of the frequency of continuous light glimpses for red light is from 35 to 30 hertz and below, and for green light from 37 to 33 hertz, which indicates excessive fatigue of the visual analyzer of the tested female athlete and is a reason for a preventive visit to an ophthalmologist with transferring the female athlete to a temporary (sparing) individual schedule of sports improvement.

Table 2. Approximate frequency indicators of red and green fluorescent lights, when they become one for the right and left eyes of the female athlete

\begin{tabular}{|l|c|c|}
\hline \multicolumn{1}{|c|}{$\begin{array}{c}\text { Object and direction of } \\
\text { measurement }\end{array}$} & Red light & Green light \\
\hline First eye (left) & $40-42$ hertz & $42-45$ hertz \\
\hline Second eye (right) & $40-42$ hertz & $42-45$ hertz \\
\hline $\begin{array}{l}\text { Lower limit of frequency, at which } \\
\text { you should consult an } \\
\text { ophthalmologist }\end{array}$ & $35-30$ hertz & $37-33$ hertz \\
\hline
\end{tabular}

Thus, the proposed method will allow the coach to quickly investigate the degree of motor fatigue of female table tennis athletes and optimally design the training process to prevent them near their maximum fatigue without reducing the effectiveness of training work. The proposed method of optical prophylactic diagnostics of motor fatigue and training overload of the visual analyzer was developed for the age of female tennis players from 8 to 15 years old and is applicable for both genders of athletes.

\section{Study the morphological characteristics of female tennis players}

In references, the idea of scientists and practitioners about the importance of longitudinal observations on the influence of some morphological signs of female tennis players on their success in mastering sports skills is increasingly activated $[6,9,10,13$, 14]. This process is observed and is strongly noticeable in terms of weight-height relations in the developing organism of female athletes, which predetermine their further success in table tennis. At the same time, the weightheight criterion for the physical development of female tennis players, being relatively simple, has a fairly significant informative nature of a prognostic character for training success $[6,7,10]$. At the same time, the actual (present) state of physical development of female athletes can be determined by their height and weight, or rather, through the ratio of the child's weight to his height through the well-known Body Mass Index (BMI) or "Kettle index", which has a number of age, quantitatively expressed gradations and is calculated by the formula: 


$$
\mathrm{BMI}=\mathrm{m} / \mathrm{h}^{2} \mathrm{x} 100,
$$

where: $\mathrm{m}$ - weight in $\mathrm{kg}, \mathrm{h}$ - height in centimeters, BMI - Kettle index

The presented method is recognized all over the world by experts in the field of sports medicine, who argue that if a child's body weight is above normal, then his body cannot function normally and sports-motor development will not be as progressive as we would like. At the same time, if the Kettle index is below normal, then dystrophic processes in the body are likely to develop, which also have an extremely negative effect on the development of the body as a whole. Thus, the coach must constantly observe the external condition of the female athletes during practical lessons and check their weight-height ratio once a month. This process must be controlled at all stages of long-term sports training. In this case, it is necessary to focus on the Kettle index from 0.21 to 0.25 .

The interdependence of the average Kettle index of parents with the Kettle index of children was reflected through a specially developed amalgamated criterion called the contingency ratio, which was calculated by the formula:

Average Kettle Index of Parents (mother + father)/2 Kettle index of observed child

$=\mathrm{Cr}$ (contingency ratio)

As a result of mathematical processing, the contingency ratio $(\mathrm{Cr})$ received the following limits:

- if $\mathbf{C r}=\mathbf{1 . 2 8}$ or less, then the child may be negatively associated with heredity and, possibly, in the future, there may be an excess of body weight to its own height;

- if $\mathrm{Cr}=1.29-1.68$, then the child is optimally associated with heredity in terms of weight and height;

- if $\mathbf{C r}=1.69$ or more, then the child may be negatively associated with heredity and, possibly, in the future, there may be a lack of body weight to his own height.
Thus, at the initial sports selection of 7-8 years old children for table tennis, it is necessary to take into account their immediate morphological state and hereditary morphological characteristics, which, with a certain confidence and predictive probability, will contribute to further sustainable sports improvement in this sport. Moreover, it is also important to relate to the control and observation of changes in the morphological state of female tennis players and during the inter-stage (selection) transfer of female athletes from the group of initial sports training to the group of sports improvement.

\section{Study the intellectual capacity of the observed female tennis players}

Table tennis, as a complex-dynamic sports game, requires from female tennis players not only motor perfection, but also proper intellectual manifestation in short-term technical and tactical situations to obtain sports success [5, 14]. That is why, we consider it extremely important to study and improve the intellectual abilities of both beginners and experienced female tennis players. At the same time, for the complexactive motor development of girls in table tennis, such basic and interdependent cognitive components as "attention", "perception", "memory", "thinking" and "imagination" are especially necessary, allowing female tennis players to be successful in all types of training and competitive manifestation $[9,10,12]$. This is especially true under unforeseen circumstances of a difficult-to-form game with an unknown opponent. That is, a female tennis player must have a sufficient age-related intellectual coordination-motor capacity. Thus, we believe that the means and methods of sports and technical development of female tennis players used should also have an intellectual orientation to improve their cognitive abilities. At the same time, we also believe that the leading cognitive component of tennis players of various sports levels is "attention", the concentration of which 
predetermines the activation of other cognitive components: perception, memory, thinking and imagination (creativity). We also believe that it is the stability and concentration of "attention" that can include the analytical abilities of female tennis players to make possible and urgent motor decisions in accordance with the game situation.

So, with female tennis players of various age levels and sports qualifications, we used the letter text of the Bourdon-Anfimov proofreading test (with the total number of letters of the Russian alphabet - 2000), in a varied combination, which a female tennis player must view in 10 minutes and at the same time emphasize the given letters of various graphics: for example, $\mathrm{K}$ and $\mathrm{R}$. The results obtained were processed accordingly, integrated into special tables, according to which the stability of the attention of the observed female tennis players was quantitatively and qualitatively assessed.

In Table 3, we present the necessary integrated data on the stability of the attention of female tennis players at various stages of sports training, determined using the BourdonAnfimov correction test. As can be seen from Table 3, at the level of the initial sports selection of girls in table tennis, due to their age-related characteristics of development, the indicator of stability of attention is allowed as "low", taking into account the fact that their initial functional and motor-developing level, as a rule, is still insufficient, and in subsequent training sessions it will improve and increase. Further, by the end of the first, second and third years of sports training, the level of attention sustainability of female tennis players increases quantitatively, but still remains qualitatively low. At the same time, by the end of the third year, the level of attention sustainability also increases quantitatively and in terms of quality reaches the level "below average". At the end of the fourth stage of sports training, female tennis players must already have an "average level" of sustainability of playing attention, which will allow them to be successful in competitive battles and fulfill the classification requirements. Of particular importance is the level of attention sustainability for female tennis players at the subsequent stages of their sports development, that is, at the fifth, sixth, seventh and eighth preparatory stages, where female tennis players must show an everincreasing level of development and state of this cognitive quality to ensure success in international competitions and achieve the desired titles.

Table 3. Indicators of the permissible-necessary quantitative and qualitative state of attention sustainability among female tennis players in different periods of long-term sports training

\begin{tabular}{|c|c|c|c|c|c|c|c|c|c|}
\hline Assessment & $\begin{array}{c}\text { Initial } \\
\text { selection }\end{array}$ & $\mathbf{1}^{\text {st }}$ stage & $\mathbf{2}^{\text {nd }}$ stage & $\mathbf{3}^{\text {rd }}$ stage & $\mathbf{4}^{\text {th }}$ stage & $\begin{array}{c}\mathbf{5}^{\text {th }} \\
\text { stage }\end{array}$ & $\mathbf{6}^{\text {th }}$ stage & $\mathbf{7}^{\text {th }}$ stage & $\mathbf{8}^{\text {th }}$ stage \\
\hline $\begin{array}{c}\text { Quantitative } \\
\text { assessment of } \\
\text { the attention } \\
\text { sustainability of } \\
\text { female tennis }\end{array}$ & Up to 2 & $\begin{array}{c}\text { From 2 } \\
\text { to 3 }\end{array}$ & $\begin{array}{c}\text { From 2 } \\
\text { to 3 }\end{array}$ & $\begin{array}{c}\text { From 4 } \\
\text { to 7 }\end{array}$ & $\begin{array}{c}\text { From 8 } \\
\text { to 11 }\end{array}$ & $\begin{array}{c}\text { From } \\
12 \text { to } \\
15\end{array}$ & $\begin{array}{c}\text { From 16 } \\
\text { to 19 }\end{array}$ & $\begin{array}{c}\text { From 16 } \\
\text { to 19 }\end{array}$ & $\begin{array}{c}\text { From } 16 \\
\text { to } 19\end{array}$ \\
\hline $\begin{array}{c}\text { Qualitative level } \\
\text { of the attention } \\
\text { sustainability of } \\
\text { female tennis } \\
\text { players }\end{array}$ & $\begin{array}{c}\text { Low } \\
\text { level }\end{array}$ & $\begin{array}{c}\text { Low } \\
\text { level }\end{array}$ & $\begin{array}{c}\text { Low } \\
\text { level }\end{array}$ & $\begin{array}{c}\text { Below } \\
\text { average }\end{array}$ & $\begin{array}{c}\text { Average } \\
\text { level }\end{array}$ & $\begin{array}{c}\text { Above } \\
\text { average }\end{array}$ & $\begin{array}{c}\text { High } \\
\text { level }\end{array}$ & $\begin{array}{c}\text { High } \\
\text { level }\end{array}$ & $\begin{array}{c}\text { High } \\
\text { level }\end{array}$ \\
\hline
\end{tabular}




\section{Conclusions}

1. In the process of analyzing and assessing the dynamics of the quantitative characteristics of the structural factors of training highly qualified female athletes, characterizing through the optimal selection of training influences, a psychological, pedagogical and methodological toolkit (a system of methods) was formed that is relevant to the tasks of the research in the psychological, pedagogical, experimental and methodological terms.

2. The analysis of the features of the functioning of the female body, in general, and during sports training, in particular, made it possible to conclude that this process must be built on the basis of these features, including the phases of the menstrual cycle.

3. To obtain objective data of the ascertaining experiment, it was necessary to study and establish the relationship of those factors that affect both the effectiveness of the training process and the final sports result.

4. In this context, the identified mechanisms influence the formation of various qualities and skills of female tennis players, serve in our research as theoretical prerequisites for substantiating the general concept of long-term training of high-level female tennis players through the optimal selection of training influences.

\section{References:}

1. Амелин А.Н. (1982). Современный настольный теннис. Москва: Физкультура и спорт. 111 с.

2. Барчукова Г. В. (1990). Настольный теннис. Москва: Физкультура и спорт. 40 с.

3. Богушас B.A. (1970). К вопросу перспективности в настольном теннисе. Материалы XXIV научно-методической конференции. Каунас: ЛГИФК, с. 56-58.

4. Богушас В.А. (1972). Стратегические проблемь настольного тенниса. Материалы XXVI научно-методической конференции. Каунас: ЛГИФК, с. 105-108.

5. Бородина Е.Ф. (1987). Интеллектуальные способности как фактор надежности спортивной деятельности. В: Псих. обеспечение подборки спортсменов. Алма-Ата: АПУ, с. 13-14.

6. Властовский В.Г. (1976). Акселеращия роста и развития детей: эпохальная $и$ внутригрупповая. Москва: МГУ. 279 с.

7. Гросул В.С. (2003). Индивидуальный план. В журнале «Настольный теннис» № 2 (37). Москва: ФАБРИКА АРТ. с. 32-35..

8. Губа В.П., Никитушкин С.Г., Квашук П.В. (1997). Индивидуальные особенности юных спортсменов. Смоленск: Инф. Ком. Агенство. 224 с.

9. Давыдов В.Ю. (1994). Морфофункииональные, психофизиологические показатели и двигательные качества детей 7-10-летнего возраста разных типов конституции. Методические рекомендации. Волгоград: ВГИФК. $32 \mathrm{c.}$

10. Камышов В.Я. и др. (1982). Динамика физического развития детей дошкольного и младшего школьного возраста. В: Проблемы современной антропологии. Минск: Наука и техника, с. 92.

11. Матвеев Л.П. (1977). Основы спортивной тренировки. Москва: Физкультура и спорт. 280 с.

12. Мокроусов Е. Общетеоретические положения спортивной тренировки для подготовки высококвалифицированных игроков на примере настольного тенниса. B: Congresul Științific Internațional «SPORT. OLIMPISM. HEALTH», ediția a II-a, 26-28 octombrie. Chisinau: USEFS, 2017, p. 118.

13. Mocrousov E. (2018). Organizational and Methodological Bases of the Long Term Training of Table Tennis Players. In: Communicative Action \& Transdisciplinarity in the Ethical Society. Iasi: LUMEN Proceedings, p. 170-182.

14. Mocrousov E. (2018). Modern analysis of the problem of forming the system of long-term table tennis players development. In: International Scientific Conference "Youth in the perspective of the Olympic movement”, 24-25 february. Brașov, p. 19. 